\title{
Application of Soft Computing Methodologies to Predict the 28-day Compressive Strength of Shotcrete: A Comparative Study of Individual and Hybrid Models
}

Rudarsko-geološko-naftni zbornik

(The Mining-Geology-Petroleum Engineering Bulletin) UDC: 622.7

DOI: $10.17794 / \operatorname{rgn} .2021 .5 .4$

Original scientific paper

\author{
Mahtab Torkan'; Hamid Kalhori ; Mohammad Hossein Jalalian ${ }^{2}$ \\ ${ }^{1}$ Faculty of Computer Engineering, Najafabad Branch, Islamic Azad University, Najafabad, Iran. \\ ${ }^{2}$ Department of Mining Engineering, Isfahan University of Technology, Isfahan 8415683111, Iran.
}

\begin{abstract}
Shotcreting is a popular construction technique with wide-ranging applications in mining and civil engineering. Compressive strength is a primary mechanical property of shotcrete with particular importance for project safety, which highly depends on its mix design. However, in practice, there is no reliable and accurate method to predict this strength. In this study, existing experimental data related to shotcretes with 59 different mix designs are used to develop a series of soft computing methodologies, including individual artificial neural network, support vector regression, and $\mathrm{M}_{5} \mathrm{P}$ model tree and their hybrids with the fuzzy c-means clustering algorithm so as to predict the 28-day compressive strength of shotcrete. Analysis of the results shows the superiority of the hybrid model over the individual models in predicting the compressive strength of shotcrete. Overall, data clustering prior to use of machine learning techniques leads to certain improvement in their performance and reliability and generalizability of their results. In particular, the $\mathrm{M}_{5} \mathrm{P}$ model tree exhibits excellent capability in anticipating the compressive strength of shotcrete.
\end{abstract}

\section{Keywords:}

shotcrete; compressive strength; machine learning techniques; hybrid model

\section{Introduction}

The importance of concrete as a construction material is indisputable. Sprayed concrete or shotcrete is a variant of concrete with an over 50 year history of use in rock/ soil support and stabilization (Moffat et al., 2017). Shotcrete can be described as a concrete or mortar that is sprayed through a high-pressure nozzle onto the surface at high velocity (ACI, 2005). Due to the compressed air used in the shotcreting process, the hardened shotcrete has slightly different properties than ordinary concrete. Thanks to properties such as high initial strength, flexibility, and good durability, shotcrete has found extensive application in mining and construction activities (Franzen et al., 2001; Kalhori \& Bagherpour, 2017; Thomas, 2008; Watanabe et al., 2010). Compressive strength is an important property of shotcrete that largely depends on its mix design. Nevertheless, quality of mix design often depends on the experience of the shotcreting crew, who rely on costly and time-consuming trial and errors to adjust the mix (ACI, 2005). Shotcrete strength is a function of many parameters including water-cement ratio, quantities of fine and coarse aggregates, admixtures, etc. Due to the large number of such parameters, it seems difficult to predict shotcrete

Corresponding author: Hamid Kalhori

hamid.kalhori@mi.iut.ac.ir strength. There are several empirical relations for predicting the strength of ordinary concrete, but the validity of these models for predicting the compressive strength of shotcrete is uncertain (Abrams, 1919; Janković et al., 2011). The prediction of shotcrete strength before shotcreting can save time, reduce operating costs, and improve operational planning and quality control.

Nowadays, data mining techniques are growing rapidly for data analysis in many fields of science. In line with this trend, these techniques have found widespread application in some branches of civil and mining engineering. One of these applications is the prediction of the mechanical and physical properties of cement-based materials. The ability of machine learning methods to predict concrete properties such as compressive strength of high-performance concrete, the tensile strength of steel fiber reinforced concrete, the elastic modulus of selfcompacting concrete, etc. has been extensively researched (Behnood et al., 2015; Cheng et al., 2014; Golafshani \& Ashour, 2016; Yücel \& Ö̉zel, 2012). In the case of compressive strength, the different data mining techniques used for prediction include an artificial neural network, a support vector machine, a classification and regression tree, neuro-fuzzy inference, and genetic programming. A summarized list of major publications in this particular line of research is provided in Table 1. In the case of shotcrete, however, the progress of research has been limited by the difference in properties and re- 
Table 1: Some recent studies to predict compressive strength by machine learning techniques

\begin{tabular}{|c|c|c|c|c|}
\hline Authors & Type of Material & Inputs & Techniques & $\begin{array}{l}\text { Performance } \\
\text { measure }\left(R^{2}\right)\end{array}$ \\
\hline $\begin{array}{l}\text { Sarıdemir (2009) } \\
\text { (Sarıdemir, 2009) }\end{array}$ & $\begin{array}{l}\text { Mortars containing } \\
\text { metakaolin }\end{array}$ & $\mathrm{AS}, \mathrm{MK} \%, \mathrm{WB}, \mathrm{SP} \%$, BS & $\begin{array}{l}\text { ANN } \\
\text { FL }\end{array}$ & $\begin{array}{l}0.9738 \\
0.9659\end{array}$ \\
\hline $\begin{array}{l}\text { Sobhani (2010) } \\
\text { (Jafar Sobhani et al., 2010) }\end{array}$ & No-slump Concrete & C, SF, W, FA, CA, Fi, WB & $\begin{array}{l}\text { MR } \\
\text { ANN } \\
\text { ANFIS }\end{array}$ & $\begin{array}{l}0.6972 \\
0.8974 \\
0.8972\end{array}$ \\
\hline $\begin{array}{l}\text { Sarıdemir }(2010) \\
\text { (Sarıdemir, 2010) }\end{array}$ & $\begin{array}{l}\text { Concretes containing } \\
\text { rice husk ash }\end{array}$ & $\begin{array}{l}\text { AS, C(30), C(40), RHA, W, } \\
\text { SP, A }\end{array}$ & GP & 0.9639 \\
\hline $\begin{array}{l}\text { Ahangar-Asr et al. (2011) } \\
\text { (Ahangar-Asr et al., 2011) }\end{array}$ & Rubber Concrete & $\begin{array}{l}\text { C, SF, W, SP, CA, FA, CR, } \\
\text { TC }\end{array}$ & $\begin{array}{l}\text { MR } \\
\text { GP } \\
\text { ANN } \\
\text { EPR }\end{array}$ & $\begin{array}{l}0.755 \\
0.964 \\
0.999 \\
0.990\end{array}$ \\
\hline $\begin{array}{l}\text { Chou et al. (2011) } \\
\text { (J. Chou et al., 2010) }\end{array}$ & $\begin{array}{l}\text { High-Performance } \\
\text { Concrete }\end{array}$ & $\begin{array}{l}\text { AS, W, C, SP, BFS, F, } \\
\text { FA, CA }\end{array}$ & $\begin{array}{l}\text { ANN } \\
\text { SVR } \\
\text { MR } \\
\text { MART } \\
\text { BRT } \\
\end{array}$ & $\begin{array}{l}0.9091 \\
0.8858 \\
0.6112 \\
0.9108 \\
0.8904\end{array}$ \\
\hline $\begin{array}{l}\text { Madandoust et al. (2012) } \\
\text { (Madandoust et al., 2012) }\end{array}$ & Concrete & $\mathrm{AS}, \mathrm{SA}, \mathrm{D}, \mathrm{L} / \mathrm{D}, \mathrm{CS}$ & $\begin{array}{l}\text { ANN } \\
\text { ANFIS }\end{array}$ & $\begin{array}{l}0.969 \\
0.988\end{array}$ \\
\hline $\begin{array}{l}\text { Safarzadegan Gilan et al. (2012) } \\
\text { (Safarzadegan Gilan et al., 2012) }\end{array}$ & $\begin{array}{l}\text { Concretes containing } \\
\text { metakaolin }\end{array}$ & AS, CA, FA, MK, W, C & $\begin{array}{l}\text { SVR+PSO } \\
\text { ANFIS }\end{array}$ & $\begin{array}{l}0.941 \\
0.823\end{array}$ \\
\hline $\begin{array}{l}\text { Sobhani et al. (2013) } \\
\text { (J Sobhani et al., 2013) }\end{array}$ & no-slump Concrete & C, SF, W, FA, CA, Fi & $\begin{array}{l}\text { ANN+GA } \\
\text { SVR+GA }\end{array}$ & $\begin{array}{l}0.964 \\
0.964 \\
\end{array}$ \\
\hline $\begin{array}{l}\text { Martins and Camões (2013) (Martins } \\
\text { \& Camões, 2013) }\end{array}$ & $\begin{array}{l}\text { Concrete containing } \\
\text { fly ash }\end{array}$ & $\begin{array}{l}\mathrm{F} \%, \mathrm{FC}, \mathrm{SF} \% \text {, TCM, FA, } \\
\mathrm{CA}, \mathrm{SP} \%, \mathrm{AS}\end{array}$ & $\begin{array}{l}\text { RT } \\
\text { MR } \\
\text { ANN } \\
\text { SVR } \\
\text { k-NN }\end{array}$ & $\begin{array}{l}0.776 \\
0.817 \\
0.867 \\
0.858 \\
0.750\end{array}$ \\
\hline $\begin{array}{l}\text { Yuan et al. (2014) } \\
\text { (Yuan et al., 2014) }\end{array}$ & Concrete & C, BFS, F, W, SP, CA, FA & $\begin{array}{l}\text { ANN } \\
\text { ANN+GA } \\
\text { ANFIS }\end{array}$ & $\begin{array}{l}0.680 \\
0.813 \\
0.950\end{array}$ \\
\hline $\begin{array}{l}\text { Nikoo et al. (2015) (Nikoo, Torabian } \\
\text { Moghadam, et al., 2015) }\end{array}$ & Concrete & $\begin{array}{l}\text { WB, MSS, G, C, S3/4, } \\
\text { S3/8, CSS }\end{array}$ & $\begin{array}{l}\text { ANN+GA } \\
\text { MR }\end{array}$ & $\begin{array}{l}0.9805 \\
0.8873\end{array}$ \\
\hline $\begin{array}{l}\text { Nikoo et al. (2015) } \\
\text { (Nikoo, Zarfam, et al., 2015) }\end{array}$ & Concrete & WB, MSG, S, C, Sl & $\begin{array}{l}\text { SOFM } \\
\text { MR } \\
\text { ANN } \\
\end{array}$ & $\begin{array}{l}0.95 \\
0.86 \\
0.61 \\
\end{array}$ \\
\hline Ayaz et al. (2015) (Ayaz et al., 2015) & $\begin{array}{l}\text { High-Volume } \\
\text { Mineral-Admixtured } \\
\text { Concrete }\end{array}$ & AS, C, F, BFS & $\begin{array}{l}\text { M5 rule } \\
\text { M5P Tree }\end{array}$ & $\begin{array}{l}0.97 \\
0.966\end{array}$ \\
\hline $\begin{array}{l}\text { Khademi et al. (2016) } \\
\text { (Khademi et al., 2017) }\end{array}$ & Concrete & $\begin{array}{l}\text { WB, MSS, G, C, S3/4, } \\
\text { S3/8, CSS }\end{array}$ & $\begin{array}{l}\text { MR } \\
\text { ANN } \\
\text { ANFIS }\end{array}$ & $\begin{array}{l}0.7456 \\
0.9226 \\
0.8212 \\
\end{array}$ \\
\hline $\begin{array}{l}\text { Chithra et al. (2016) } \\
\text { (Chithra et al., 2016) }\end{array}$ & $\begin{array}{l}\text { High Performance } \\
\text { Concrete containing } \\
\text { nano silica and copper } \\
\text { slag }\end{array}$ & C, NS, FA, COS, AS, SP & $\begin{array}{l}\text { MR } \\
\text { ANN }\end{array}$ & $\begin{array}{l}0.6717 \\
0.9980\end{array}$ \\
\hline
\end{tabular}

quirements of shotcrete as compared to ordinary concrete. For example, coarse aggregates used in shotcretes are smaller than those typically used in concretes, the initial compressive strength is more important for shotcrete than for ordinary concrete, and the use of compressed air in shotcreting results in a widespread appearance of small air bubbles in the hardened shotcrete (Watanabe et al., 2010). Considering the good track record of machine learning algorithms in predicting the compressive strength of concretes and the widespread use of shotcrete in mining and civil engineering activities, the authors of this paper utilized the experimental data collected by laboratory testing to develop several models for predicting the compressive strength of shotcrete.

In the majority of studies in this line of research, artificial intelligence techniques have been utilized in their 
Table 1: Continued

\begin{tabular}{|c|c|c|c|c|}
\hline Authors & Type of Material & Inputs & Techniques & $\begin{array}{l}\text { Performance } \\
\text { measure }\left(\mathbf{R}^{2}\right)\end{array}$ \\
\hline $\begin{array}{l}\text { Hoang et al. (2016) } \\
\text { (Hoang et al., 2016) }\end{array}$ & $\begin{array}{l}\text { High Performance } \\
\text { Concrete }\end{array}$ & $\begin{array}{l}\text { C, FA, CA(5-10mm), } \\
\text { CA(10-20mm), W, SP, AS }\end{array}$ & $\begin{array}{l}\text { GPR } \\
\text { SVR } \\
\text { ANN }\end{array}$ & $\begin{array}{l}0.9 \\
0.89 \\
0.85\end{array}$ \\
\hline $\begin{array}{l}\text { Asteris and Kolovos (2017) } \\
\text { (Asteris \& Kolovos, 2017) }\end{array}$ & $\begin{array}{l}\text { Self-compacting } \\
\text { Concrete }\end{array}$ & $\begin{array}{l}\text { C, CA, FA, W, LP, F, BFS, } \\
\text { SF, RHA, SP, VMA }\end{array}$ & ANN & 0.966 \\
\hline $\begin{array}{l}\text { Behnood et al. (2017) } \\
\text { (Behnood et al., 2017) }\end{array}$ & $\begin{array}{l}\text { Normal and } \\
\text { High-Performance } \\
\text { Concretes }\end{array}$ & $\begin{array}{l}\text { C, F, BFS, W, SP, CA, } \\
\text { FA, AS }\end{array}$ & M5P Tree & 0.900 \\
\hline $\begin{array}{l}\text { Tenza-Abril et al. } \\
\text { (2018) (Tenza-Abril et al., 2018) }\end{array}$ & $\begin{array}{l}\text { segregated } \\
\text { lightweight concrete }\end{array}$ & C, W, FA & ANN & 0.825 \\
\hline $\begin{array}{l}\text { Naderpour et al. } \\
\text { (2018) (Naderpour et al., 2018) }\end{array}$ & $\begin{array}{l}\text { recycled aggregate } \\
\text { concrete }\end{array}$ & $\begin{array}{l}\text { WCR, WA, FA, NCA, } \\
\text { RCA, WT }\end{array}$ & ANN & 0.796 \\
\hline $\begin{array}{l}\text { Hammoudi et al. } \\
\text { (2019) } \\
\text { (Hammoudi et al., 2019) }\end{array}$ & $\begin{array}{l}\text { recycled aggregate } \\
\text { concrete }\end{array}$ & C, NCA, RCA, Sl & $\begin{array}{l}\text { RSM } \\
\text { ANN }\end{array}$ & $\begin{array}{l}0.9900 \\
0.9980\end{array}$ \\
\hline $\begin{array}{l}\text { Kalhori and Bagherpour } \\
\text { (2019) } \\
\text { (Kalhori \& Bagherpour, 2019) }\end{array}$ & shotcrete & $\mathrm{C}, \mathrm{W}, \mathrm{FA}, \mathrm{CA}, \mathrm{w} / \mathrm{c}, \mathrm{mc}$ & $\begin{array}{l}\text { ANN } \\
\text { SVR }\end{array}$ & $\begin{array}{l}0.8731 \\
0.8629\end{array}$ \\
\hline $\begin{array}{l}\text { Feng et al. } \\
(2020) \text { (Feng et al., 2020) }\end{array}$ & Concrete & $\begin{array}{l}\text { C, W, CA, FA, SP, BFS, } \\
\text { F, CT }\end{array}$ & $\begin{array}{l}\text { AdaBoost } \\
\text { ANN } \\
\text { SVM }\end{array}$ & $\begin{array}{l}0.982 \\
0.903 \\
0.855\end{array}$ \\
\hline $\begin{array}{l}\text { Kaloop et al. } \\
(2020) \text { (Kaloop et al., 2020) }\end{array}$ & $\begin{array}{l}\text { High Performance } \\
\text { Concrete }\end{array}$ & $\begin{array}{l}\text { C, F, BFS, W, SP, CA, FA, } \\
\text { Age }\end{array}$ & $\begin{array}{l}\text { MARS } \\
\text { MARS-GBM } \\
\text { MARS-KRR } \\
\text { MARS-GPR }\end{array}$ & $\begin{array}{l}0.87 \\
0.984 \\
0.926 \\
0.892\end{array}$ \\
\hline $\begin{array}{l}\text { Ganesh and Muthukannan } \\
\text { (2021) } \\
\text { (Ganesh \& Muthukannan, 2021) }\end{array}$ & $\begin{array}{l}\text { high performance } \\
\text { sustainable optimized } \\
\text { fiber reinforced } \\
\text { geopolymer concrete }\end{array}$ & Age, CT, DOF & ANN & 0.98 \\
\hline $\begin{array}{l}\text { Zho et al. } \\
\text { (2021) (Zhu et al., 2021) }\end{array}$ & $\begin{array}{l}\text { recycled aggregate } \\
\text { concrete }\end{array}$ & $\mathrm{CC}, \mathrm{CI}, \mathrm{WA}, \mathrm{w} / \mathrm{c}$ & GCA & 0.92 \\
\hline \multicolumn{5}{|c|}{$\begin{array}{l}\text { AS: Age of Specimen, MK: Metakaolin replacement, WB: Water-Binder ratio, SP: Superplasticizer, BS: Binder-Sand ratio, C: } \\
\text { Cement, SF: Silica Fume, W: Water, FA: Fine aggregate, CA: Coarse aggregate, NCA: natural coarse aggregate, RCA: recycled } \\
\text { coarse aggregate, Fi: Filler, RHA: Rice Husk Ash, A: Aggregate, CT: curing time, CR: Crumb Rubber, TC: Tyre Chip, BFS: } \\
\text { Blast-furnace slag, F: Fly ash, SA: Size of Aggregate, D: Core Diameter, DOF: dosage of fiber, L/D: Length-to-Diameter ratio, } \\
\text { CS: Core Strength, FC: Fly ash Characteristics, TCM: Total Cementitious Material, MSS: Maximum Size of Sand, G: Gravel, } \\
\text { S: Sand, CSS: Coefficient of Soft Sand, MSG: Maximum Size of Gravel, Sl: Slump, NS: Nano Silica, COS: Copper Slag, LP: } \\
\text { Limestone Powder, VMA: Viscosity Modifying Admixtures, CC: clay content, CI: crush index, WA: water absorption, WT: } \\
\text { water-total material ratio, w/c: water to cement ratio, and mc: micro-silica. }\end{array}$} \\
\hline \multicolumn{5}{|c|}{$\begin{array}{l}\text { ANN: Artificial neural network, FL: Fuzzy logic, MR: Multiple Regression, ANFIS: Adaptive neuro-fuzzy inference system, } \\
\text { GP: Genetic programming, EPR: Evolutionary polynomial regression, SVR: Support vector regression, MART: Multiple addi- } \\
\text { tive Regression trees, BRT: Bagging regression trees, PSO: Particle swarm optimization, GA: Genetic algorithm, RT: Regres- } \\
\text { sion Trees, RSM: response surface methodology, k-NN: k-Nearest Neighbours, SOFM: Self Organization Feature Map, GPR: } \\
\text { Gaussian Process Regression, MARS: Multivariate adaptive regression splines, GBM: Gradient boosting machines, KRR: } \\
\text { Kernel ridge regression, and GCA: gray correlation analysis. }\end{array}$} \\
\hline
\end{tabular}

basic form or with minor modifications (J.-S. Chou \& Pham, 2013). Clearly, given the differences in the constituting parts of cement-based materials in different parts of the world, these techniques are not powerful enough to be further extended for all kinds of concrete. Using a preliminary phase of data clustering based on the greatest similarity between records, prior to data processing with artificial intelligence techniques, may be able to improve the prediction power and precision of data mining methods.

Despite the widespread use of shotcrete in mining and construction activities during the past decades, there is still no strong quantitative method for the realistic anticipation of the compressive strength of shotcrete based on its mix design. Therefore, this study aimed to develop a probabilistic model for the anticipation of the 28-day 
compressive strength of shotcrete. This aim was pursued by the use of three artificial intelligence techniques, namely artificial neural network, support vector regression, and M5P model tree, as well as their hybrids with a clustering method called fuzzy $\mathrm{C}$-means (FCM). In the hybrid models, the aforementioned artificial intelligence techniques are applied to the clusters constructed by FCM rather than the entire dataset. In the end, a comparison is made between the performance of individual models and their hybrids in predicting the compressive strengths of shotcrete. The experimental data used in this research is a dataset compiled from the records of 59 laboratory tests conducted during the construction of the Karun-3 dam project in Iran.

\section{Methodology}

Machine learning is the main branch of artificial intelligence that utilizes learning methods to recognize complex patterns in experimental data (Taffese \& Sistonen, 2017). This method has been successfully used for the simulation of material behavior in a variety of fields (J.S. Chou et al., 2014). In this study, the compressive strength of shotcrete is predicted with three machine learning methodologies: artificial neural network, support vector machine, and M5P model tree, with FCM used in advance to cluster the data. A brief description of the methods utilized for prediction is provided in the following section.

\subsection{Artificial neural network (ANN)}

An artificial neural network is an information processing system with functional characteristics similar to biological neural networks. Being generalizations of mathematical models of the human brain or neurobiology, artificial neural networks are based on the following assumptions:

1- information is processed in a large number of simple elements called neurons. 2- Signals are transmitted between neurons along the communication link. 3- Each communication link has a given weight which is multiplied by the transmitted signal in a general neural network. 4- Every neuron adds an activation function (usually a non-linear function) to the input (the sum of weighted input signals) in order to determine the output signal (Friedman \& Kandel, 1999). ANNs are characterized by (1) the pattern of the relationship between neurons (architecture), (2) how connections are weighted (training method or algorithm), and (3) the activation (transmission) function. Neural networks are particularly useful for the modeling of phenomena where there is no specific definition of or clear understanding of internal processes (Beale \& Jackson, 1990; Fausett, 1994). Feedforward neural network is the best-known variant of ANN and has widespread application in many applied sciences. Generally, feed-forward networks, which are also known as multilayer perceptron (MLP), consist of one input layer, one or more hidden layers and one output layer (Adhikary \& Mutsuyoshi, 2006).

\subsection{Support vector regression (SVR)}

First developed in 1995 by Vapnik, a support vector machine is a supervised learning model with two variations: support vector regression (SVR) and support vector classification (SVC) (Cortes \& Vapnik, 1995). SVR is known for its substantial ability to solve nonlinear problems and has been successfully used for such purpose in various fields (Ghasemi, Kalhori, \& Bagherpour, 2016). The core concept of SVR is to map the input data to an $n$-dimensional feature space by means of a non-linear mapping procedure, which is usually a kernel function (Golafshani \& Behnood, 2018). As a result, a nonlinear solution in lower-dimensional input space will be corresponding to a linear solution in the higher-dimensional feature space. The kernel function to be used for mapping can be, for example, a linear kernel function $k x_{t}, x_{k}=x_{t}, x_{k}$, a polynomial kernel function $k x_{t}, x_{k}=\left(x_{t}, x_{k}+1\right)^{a}, d>0$, a radial basis function (RBF) $k x_{t}, x_{k}=\exp \left(-y x_{t}, x_{k}^{2}\right), y>0$, etc. (Gunn, 1998). In highly nonlinear spaces, RBF usually yields better results than other kernel functions, so it is also more suitable for the purpose of this study. The generalizability of SVR results highly depends on its learning parameters, such as the penalty factor (C) and the deviation (width) of the radial basis function kernel $(\mathrm{g})$.

\section{3. $M_{5} P$ model tree algorithm}

The concept of model tree called M5 was first introduced in 1992 by Quinlan as a new learning model for prediction problems (Quinlan, 1992). Model trees obtain a structural display of data and a piecewise linear fit of the class. They are in fact a generalized form of the decision tree or regression tree in which discrete class labels or numerical values in the leaves are replaced by linear regression functions. These models are particularly suitable for handling large volumes of data sets with a high number of features and dimensions. The prediction accuracy of model trees is comparable to other data mining techniques, such as ANN and CART. However, the real advantage of model trees is their ability to provide a description of inherent patterns of relationships between data with the help of rules and regression equations; an ability that is absent in other intelligent models, such as ANN and SVM, where those relations remain hidden. Even though model trees are simple, they are a robust and accurate method for simulating the patterns and relationships for large data sets (EtemadShahidi \& Ghaemi, 2011; Etemad-Shahidi \& Mahjoobi, 2009; Ghasemi, Kalhori, Bagherpour, et al., 2016). Introduced by Wang and Witten, the M5P algorithm is a modified version of the standard M5 algorithm and consists of four main steps (Wang \& Witten, 1997). In the first step of M5P, a regression tree is constructed by splitting the instance space into several sub-spaces. 
Criteria for division are used so that they minimize the intra-subset variation in the values down from the root through the branch to the node. The standard deviation of the values that reach through the branch from the root to the node is used to measure the variation. The splitting criterion is the minimization of error within each subset, which is measured by the standard deviation of the instance values that reach a node through branches, starting from the root. This is achieved by calculating the expected reduction in error from testing each attribute at the node and selecting the attribute that maximizes the expected error reduction. This splitting process stops when the output values of the instances that reach a node vary by less than $5 \%$ of the standard deviation of the original dataset, or when only a few instances remain. The standard deviation reduction (SDR) is calculated by Equation 1 (Khoshnoudian et al., 2013).

$$
S D R=s d(T)-\sum_{i} \frac{\left|T_{i}\right|}{|T|} \times s d\left(T_{i}\right)
$$

where $T$ is the set of records that reach the node, $T_{i}$ are the sets that are resulted from splitting the node according to the chosen attribute, and sd denotes the standard deviation (Wang \& Witten, 1997). In the next step, M5P calculates, for every interior node, a linear multiple regression model based on the values pertaining to that node and all the attributes that participate in tests in the subtree rooted at that node. Then, linear regression models are simplified by removing the attributes if this results in a lower expected error for future data. After this simplification, a pruning technique is used to overcome the over-training problem. The tree is pruned from the leaves if SDR for linear model in the root of sub-tree is smaller or equal to the expected error for the sub-tree. In the final step, a smoothing process is performed to compensate for sharp discontinuities that may occur between the adjacent linear models in the leaves of the pruned tree. This smoothing process often improves the prediction, especially for models based on training sets containing a small number of instances (Bonakdar \& Etemad-Shahidi, 2011).

\subsection{Fuzzy c-means (FCM)}

The fuzzy c-means (FCM) algorithm, first developed by Dunn and then improved by Bezdek, is one of the well-known and most widely used fuzzy clustering techniques (Bezdek, 1981; Dunn, 1973). The primary motive for development of FCM was to address the deficiency in working with overlapping groups shown by the hard algorithm k-means (Silva Filho et al., 2015). Therefore, in accordance with fuzzy logic, each data can have a membership value between $[0,1]$, and can belong to two or more clusters (Ren et al., 2019). In FCM, each cluster is described with respect to its center and the distance between a point and a cluster is measured by Euclidean distance. FCM relies on three basic operators: a set of prototypes $V$, a fuzzy partition matrix $U$, and an objective function $J(U, V)$. This method operates based on the minimization of objective function 2 :

$$
\mathrm{J}(\mathrm{U}, \mathrm{V})=\sum_{i=1}^{C} \sum_{j=1}^{N} u_{i j}^{m}\left\|x_{j}-v_{i}\right\|^{2}, 1 \leq m \leq \infty
$$

where $x_{j}$ is the $j$ th measured data point or object, $v_{i}$ is the center of cluster $i, u_{i j}$ is the membership degree of $x_{j}$ with respect to cluster $i, m$ is a weight exponent controlling the degree of fuzzification, and $\|*\|$ is the Euclidean norm, which represents the similarity between any measured data and the center. In FCM, the minimization process is performed by an iterative algorithm. In each iteration, the values of $u_{i j}$ and $v_{i}$ are updated by formulas 3 and 4 :

$$
\begin{gathered}
u_{i j}=\frac{1}{\sum_{k=1}^{C}\left(\frac{\left\|x_{j}-v_{i}\right\|}{\left\|x_{j}-v_{k}\right\|}\right)^{\frac{2}{m-1}}} \\
v_{i}=\frac{\sum_{j=1}^{N} u_{i j}^{m} \cdot x_{j}}{\sum_{j=1}^{N} u_{i j}^{m}}, 1 \leq i \leq C
\end{gathered}
$$

Once FCM processing is complete, membership degrees decide which individual belongs to which cluster. Each point joins to each cluster with a certain membership degree, but the cluster which gets the highest membership degree constitutes the actual cluster of that point (Esme \& Karlik, 2016).

\subsection{Data Preparation and Description}

As mentioned earlier, this study uses a dataset compiled from the records of 59 laboratory tests, each with

Table 2: Mix components and range of input and output parameters.

\begin{tabular}{|l|c|c|c|c|}
\hline Input variables & Minimum & Average & Maximum & Standard deviation \\
\hline Cement $\left(\mathrm{kg} / \mathrm{m}^{3}\right)$ & 290 & 400 & 570 & 70.852 \\
\hline Water $\left(\mathrm{kg} / \mathrm{m}^{3}\right)$ & 130 & 196.96 & 247 & 27.02 \\
\hline Fine aggregate $\left(\mathrm{kg} / \mathrm{m}^{3}\right)$ & 770 & 1058.39 & 1363 & 229.75 \\
\hline Coarse aggregate $(\mathrm{kg} / \mathrm{m} 3)$ & 418 & 456.83 & 555 & 45.18 \\
\hline Micro silica $\left(\mathrm{kg} / \mathrm{m}^{3}\right)$ & 0 & 33.59 & 81 & 21.83 \\
\hline Output variable & & & & 70.84 \\
\hline 28-days Compressive Strength of shotcrete $\left(\mathrm{kg} / \mathrm{cm}^{2}\right)$ & 277 & 397.64 & 547 & \\
\hline
\end{tabular}




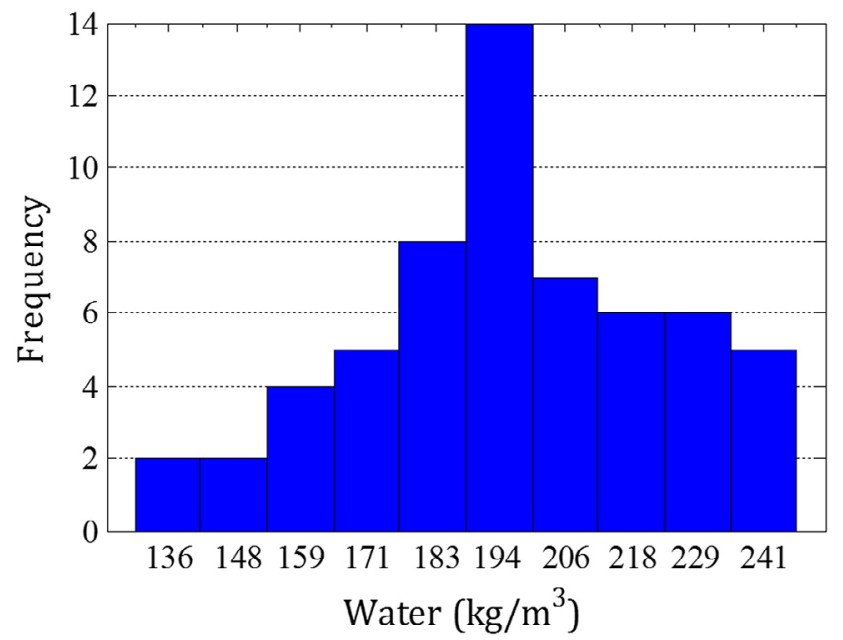

(a)

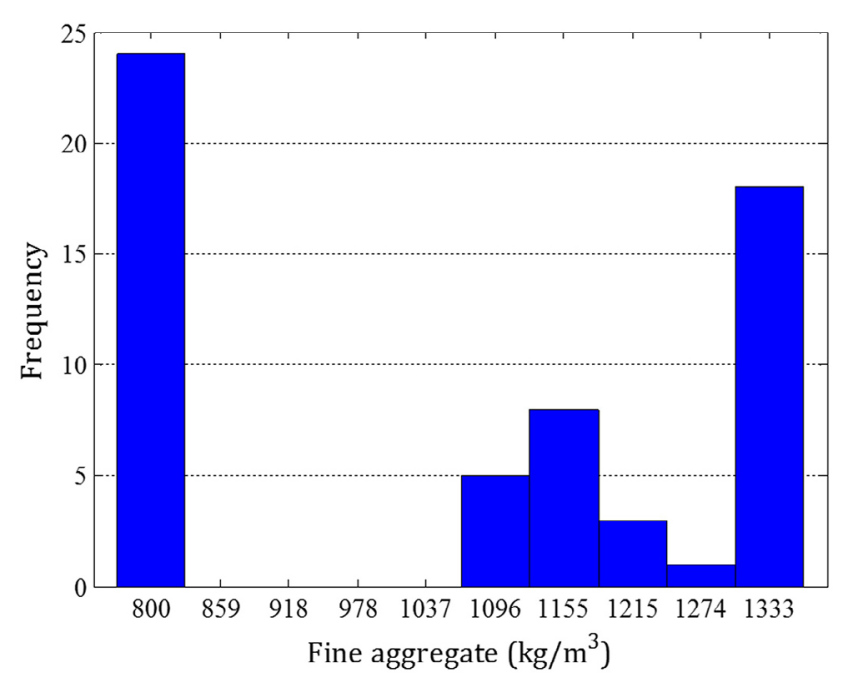

(c)



(e)

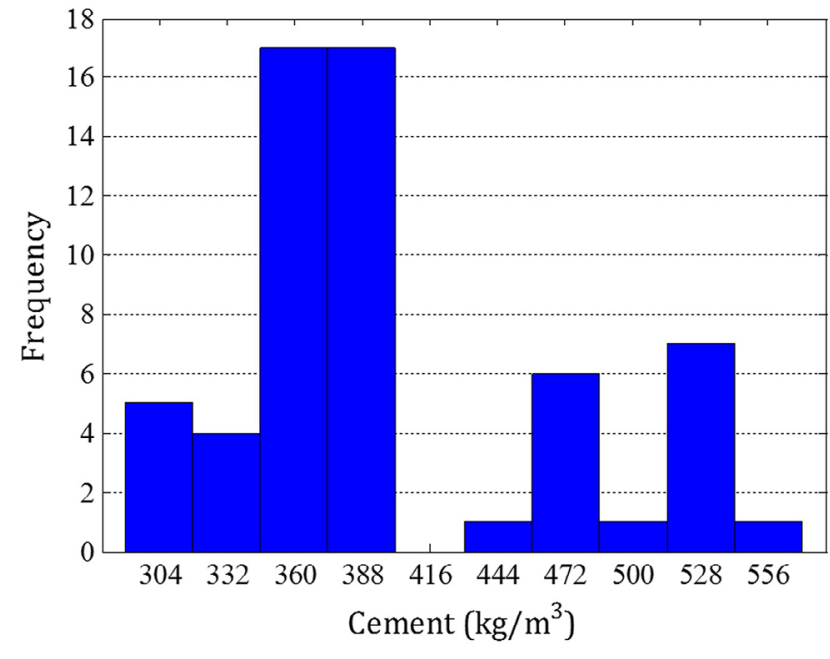

(b)

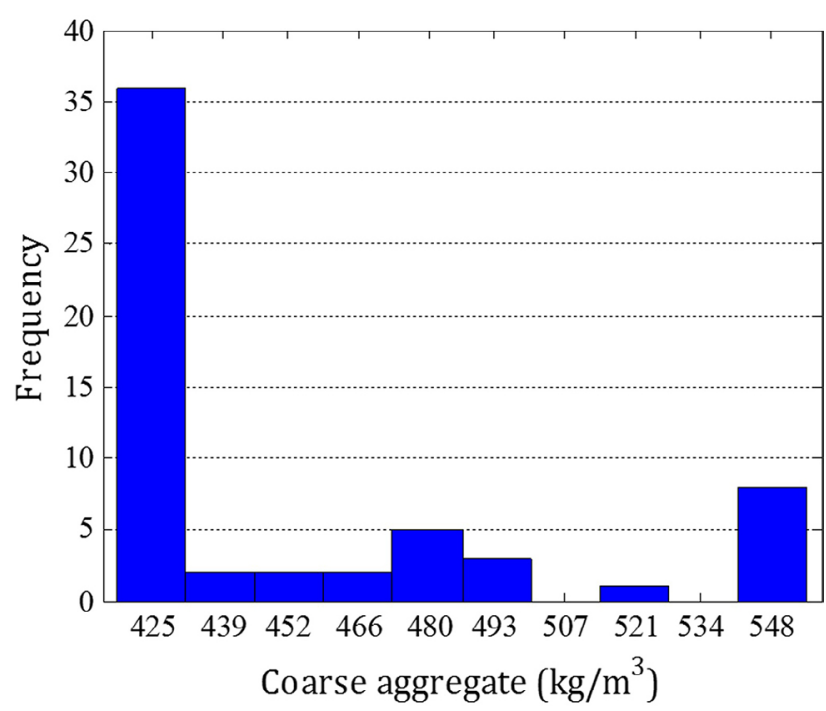

(d)



(f)

Figure 1: Histograms of: (a) water; (b) cement; (c) fine aggregate; (d) coarse aggregate; (e) Micro silica; (f) compressive strength. 




Figure 2: Architecture of the proposed Neural network.

Table 3: General characteristics of the developed Neural network.

\begin{tabular}{|c|c|c|c|c|c|c|}
\hline \multirow{2}{*}{ Type } & \multirow{2}{*}{$\begin{array}{c}\text { Training } \\
\text { method/algorithm }\end{array}$} & \multicolumn{3}{|c|}{ No. of neurons per layers } & \multirow{2}{*}{$\begin{array}{c}\text { Activation } \\
\text { function in } \mathrm{HL}\end{array}$} & \multirow{2}{*}{$\begin{array}{l}\text { Activation function } \\
\text { in output layer }\end{array}$} \\
\hline & & Input & Hidden & Output & & \\
\hline $\begin{array}{l}\text { Feed-forward } \\
\text { back-propagation network }\end{array}$ & $\begin{array}{c}\text { Supervised/Levenberg } \\
\text { - Marquardt BP }\end{array}$ & 5 & 7 & 1 & Tansig & $\begin{array}{l}\text { Linear transfer } \\
\text { function }\end{array}$ \\
\hline
\end{tabular}

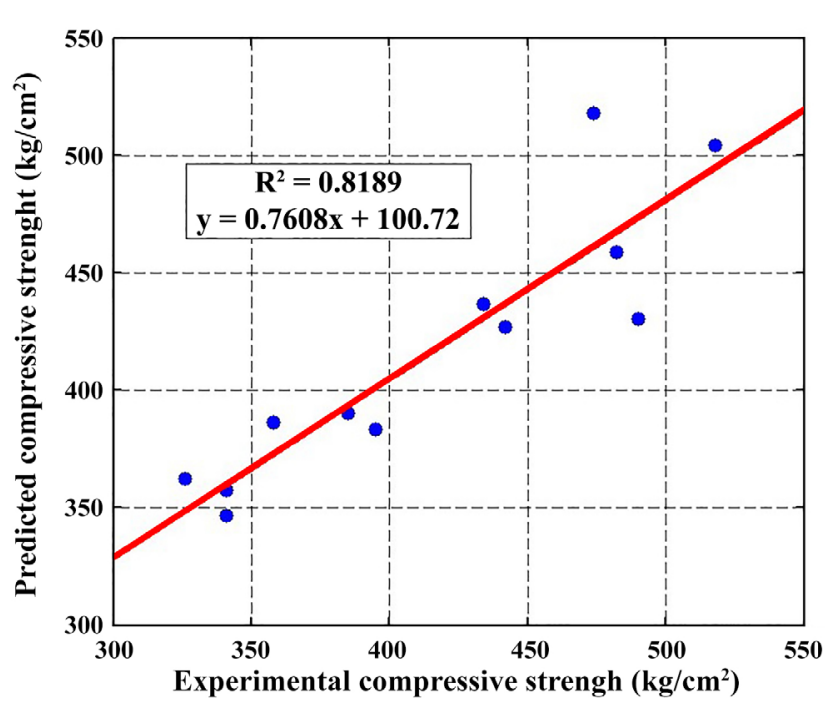

Figure 3: Comparison of measured and predicted values by ANN model for testing data.

three replicates, conducted based on different shotcrete mix designs during the construction of Karun-3 dam project in Iran. In these data, five mix design parameters, namely the quantities of cement, water, fine aggregates, coarse aggregates, and micro silica, were used as input variables, and the 28-day compressive strength of shotcrete was considered as the output variable. The statistical description of these variables is provided in Table $\mathbf{2}$, and their histogram is illustrated in Figure 1.

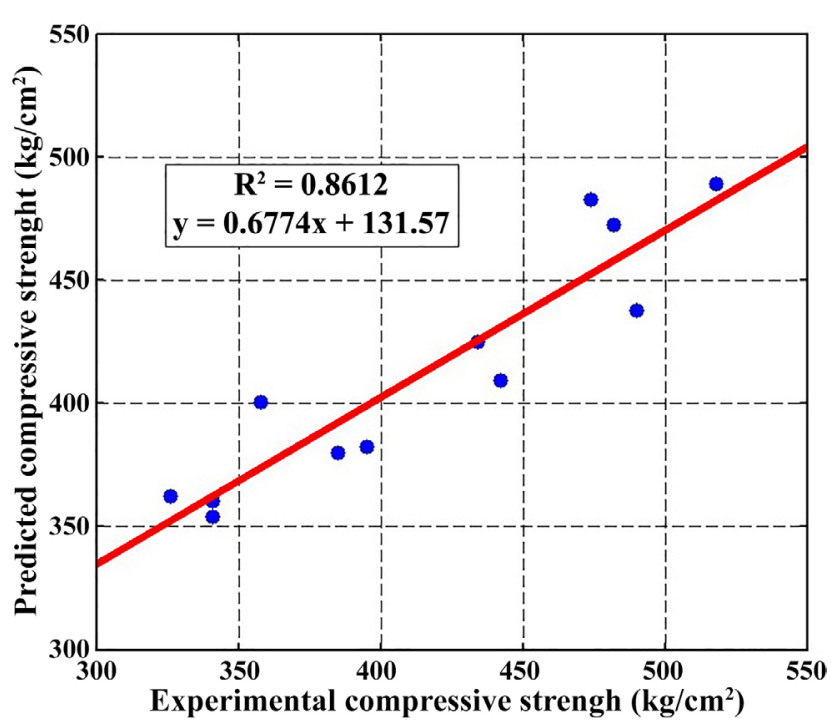

Figure 4: Comparison of measured and predicted values by SVR model for testing data.

To investigate the prediction ability of the developed models, data were randomly divided into two separate groups, one for training and another for testing purpose. The training dataset consisted of $47(80 \%)$ input-output pairs, which were used as training instances. The testing dataset consisted of $12(20 \%)$ input-output pairs, which were withheld from the training process and were used only at the testing stage to gauge the prediction ability of the models. 


\subsection{Performance Evaluation Criteria}

To estimate the anticipation accuracy of the models, their outputs needed to be compared with the actual values measured in the tests. This comparison was made based on three statistical measures: the coefficient of de- termination $\left(\mathrm{R}^{2}\right)$, the Mean Absolute Percentage Error (MAPE), and the Root Mean Squared Error (RMSE). The coefficient of determination represents the degree of similarity between the predicted and measured values. The closer $\mathrm{R}^{2}$ is to one, the better the prediction power. The MAPE is another measure of prediction accuracy,

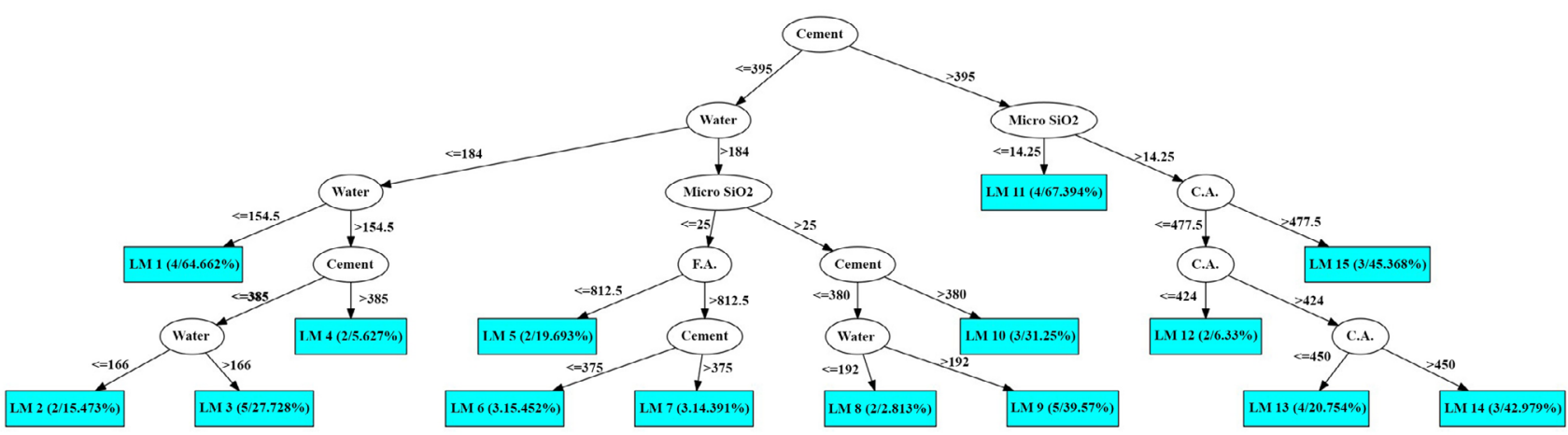

Figure 5: Structure of the unpruned $\mathrm{M}_{5} \mathrm{P}$ model tree.

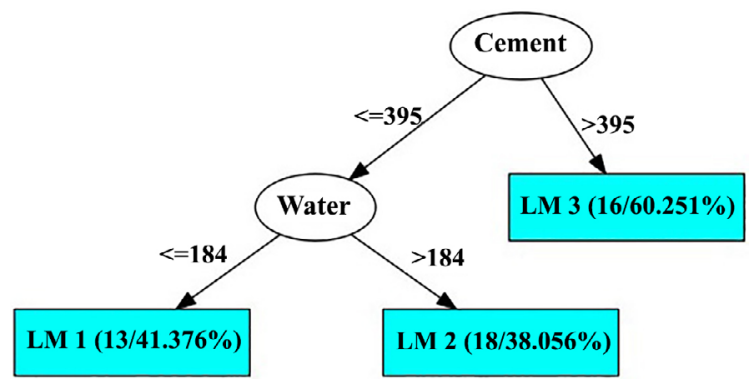

Figure 6: Structure of the pruned $\mathrm{M}_{5} \mathrm{P}$ model tree. particularly for quantitative predictions, and is usually expressed as a percentage. RMSE is the mean of the perpendicular distance of a given data point from the fitted line. For both MAPE and RMSE, the closer the measure is to zero, the higher the accuracy of the model. These statistical parameters can be obtained from equations $\mathbf{5}$, 6 and 7.

$$
R^{2}=1-\frac{\sum_{i=1}^{N}\left(T_{i}-P_{i}\right)^{2}}{\sum_{i=1}^{N}\left(T_{i}-\bar{T}\right)^{2}}
$$

Table 4: Linear models (LMs) for the $\mathrm{M}_{5} \mathrm{P}$ model trees.

\begin{tabular}{|c|c|c|}
\hline & No. & Linear regression model \\
\hline & $\begin{array}{l}\text { LM } 1 \\
\text { LM } 2 \\
\text { LM 3 } \\
\text { LM 4 } \\
\text { LM 5 } \\
\text { LM 6 } \\
\text { LM 7 } \\
\text { LM } 8 \\
\text { LM 9 } \\
\text { LM 10 } \\
\text { LM 11 } \\
\text { LM 12 } \\
\text { LM 13 } \\
\text { LM 14 } \\
\text { LM 15 }\end{array}$ & 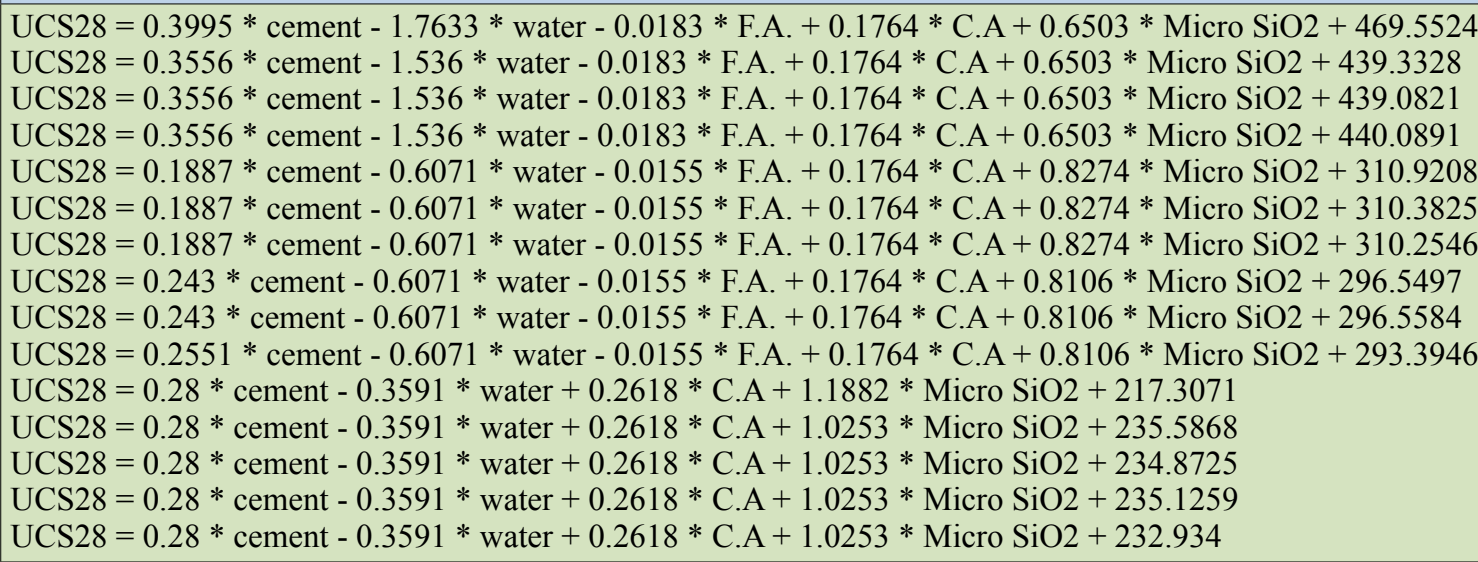 \\
\hline & $\begin{array}{l}\text { LM } 1 \\
\text { LM } 2 \\
\text { LM } 3\end{array}$ & $\begin{array}{l}\text { UCS28 }=0.4557 * \text { cement }-2.0542 * \text { water }-0.0183 * \text { F.A. }+0.1764 * \text { C.A }+0.6503 * \text { Micro SiO2 }+493.3872 \\
\text { UCS28 }=0.1887 * \text { cement }-0.6071 * \text { water }-0.0155 * \text { F.A. }+0.1764 * \text { C.A }+0.9397 * \text { Micro SiO2 }+310.4558 \\
\text { UCS28 }=0.28 * \text { cement }-0.3591 * \text { water }+0.2618 * \text { C.A }+1.3348 * \text { Micro SiO2 }+218.1533\end{array}$ \\
\hline \multicolumn{3}{|c|}{$\begin{array}{l}\text { UCS: Uniaxial Compressive Strength of shotcrete } \\
\text { cement: Cement content } \\
\text { water: Water content } \\
\text { F.A.: Fine Aggregate content } \\
\text { C.A.: Coarse Aggregate content } \\
\text { micro silica: Micro silica content }\end{array}$} \\
\hline
\end{tabular}




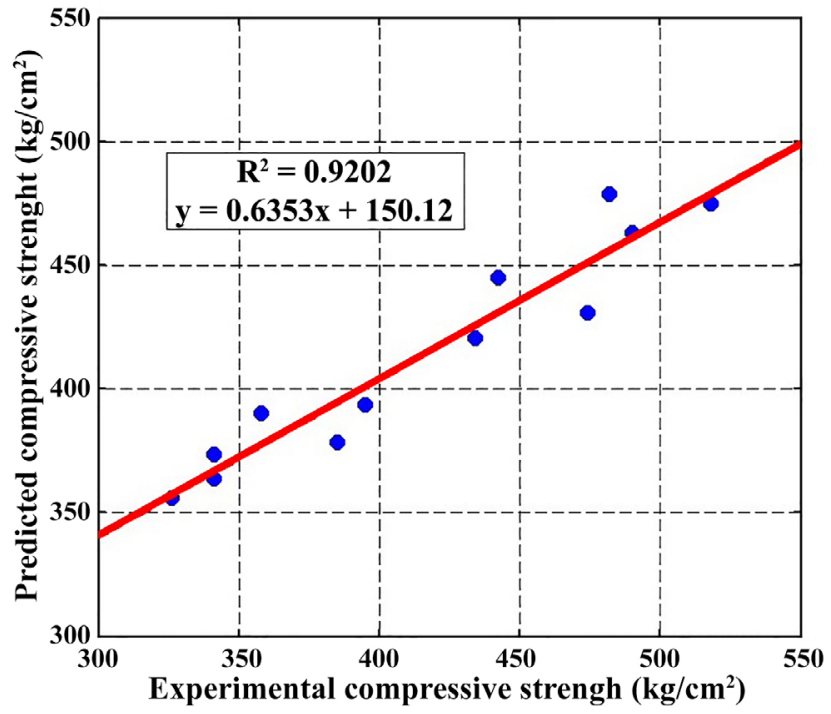

Figure 7: Comparison of measured and predicted values by unpruned $\mathrm{M}_{5} \mathrm{P}$ model tree for testing data.

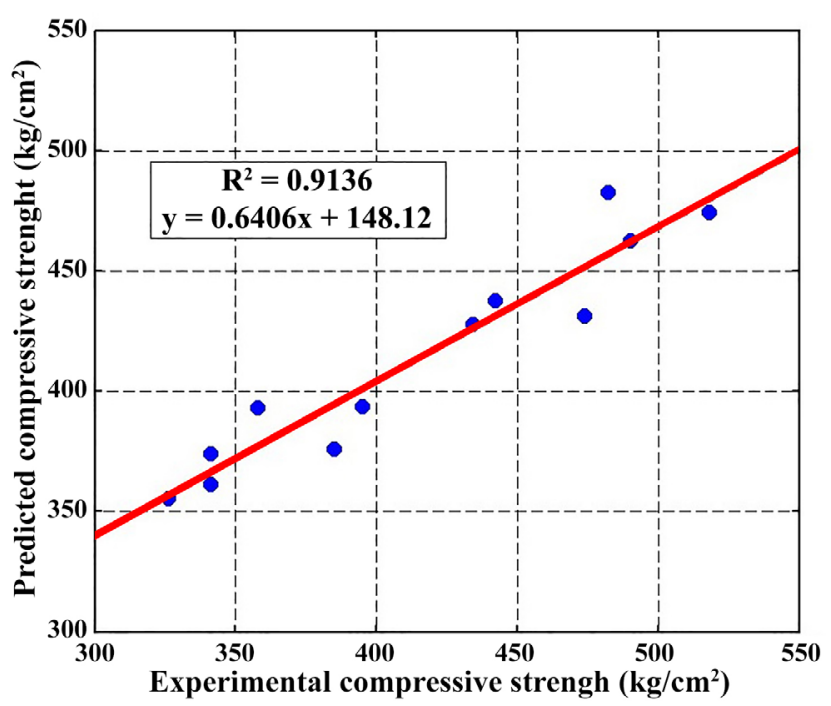

Figure 8: Comparison of measured and predicted values by pruned $\mathrm{M}_{5} \mathrm{P}$ model tree for testing data.

$$
\begin{gathered}
\operatorname{MAPE}(\%)=\frac{1}{N} \sum_{i=1}^{N} \frac{\left|T_{i}-P_{i}\right|}{T_{i}} \times 100 \\
R M S E=\sqrt{\frac{1}{N} \sum_{i=1}^{N}\left(T_{i}-P_{i}\right)^{2}}
\end{gathered}
$$

Where $T_{i}$ denotes the measured values, $P_{i}$ denotes the predicted value, $\bar{T}$ is the mean of the measured values, and $\mathrm{N}$ is the total number of input data.

\section{Modelling and results}

The compressive strength of shotcrete is a function of several parameters, including the amount of different components, curing conditions, type of cement, type and quality of aggregates, admixtures and plasticizers, etc., which all need to be incorporated into the model for it to make accurate predictions. However, this is almost impossible because of the diversity and variability of these parameters, which require us to incorporate a large number of inputs, which in turn leads to overlearning and overcomplexity of the model. Therefore, for modelling, we handpicked some of the primary determinants of compressive strength of shotcrete including the quantities of cement, water, fine aggregates, coarse aggregates, and micro silica. In view of our objective, which was to inquire the possibility of using intelligent methods to predict the compressive strength of shotcrete, and also assess the effect of using a preliminary data clustering phase prior to data mining technique on the prediction accuracy, development of the models is described in two section: one dedicated to individual models, and another to hybrid models, and finally, all models are compared based on the aforementioned statistical measures.

\subsection{Development of individual models}

This section describes the development of three machine learning models used as benchmark models, namely artificial neural network (ANN), support vector regression (SVR) and M5P model tree.

\subsubsection{Artificial neural network}

ANN models can be developed with various algorithms and topologies. ANN architecture consists of an input layer, an output layer, and hidden layers, each containing a number of neurons linked through weighted connections. The number of neurons in the input and output layers is equal to the number of input and output variables. However, the number of hidden layers and the neurons of each hidden layer is variable and greatly affects the performance of the model. Using a single hidden layer reduces the complexity of the model. Determining the number of hidden layer neurons is an important and sensitive part of the development of ANN model. This issue has been investigated by numerous researchers, who have proposed several methods and equations for this purpose (Caudill, 1988; Hecht-Nielsen, 1989; Kaastra \& Boyd, 1996; Kanellopoulos \& Wilkinson, 1997; Ripley, 1993). Considering $2 \mathrm{Ni}+1$ as the maximum number of neurons required in the hidden layer, we tested the model with different numbers of neurons and chose the one with the best performance. The schematic structure and general characteristics of the ANN model used in this study are presented in Figure 2 and Table 3, respectively. As can be seen, the single hidden layer of this ANN model contains 7 neurons. The ANN model was implemented in MATLAB. As noted above, approximately $80 \%$ of data was used to train the model and the remaining 20\% was reserved for testing. In Figure 3, the outputs of this ANN model are compared with the measured compressive strength values. 


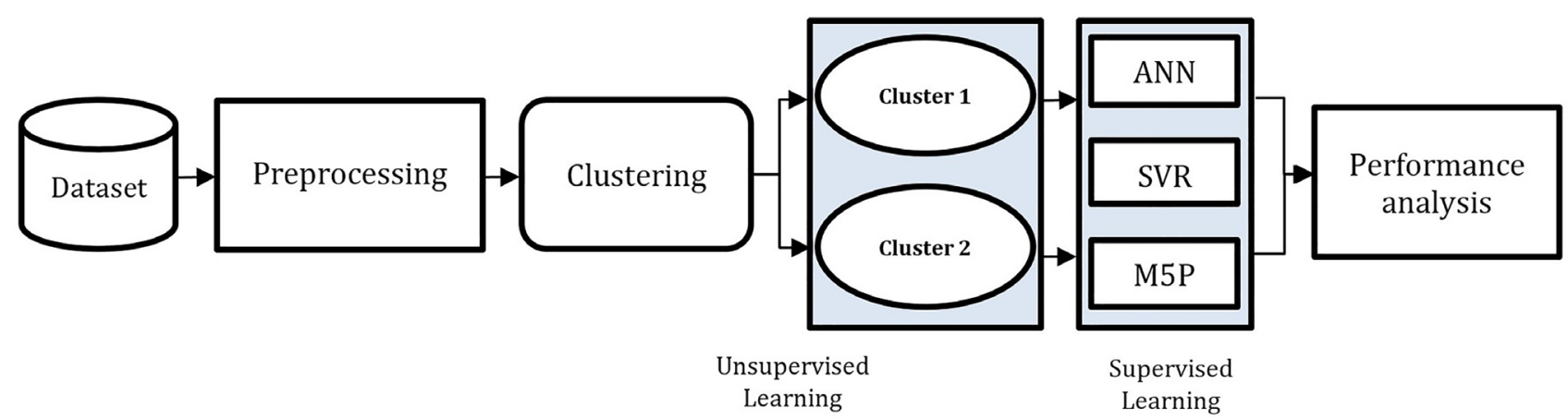

Figure 9: Methodology of the proposed models.

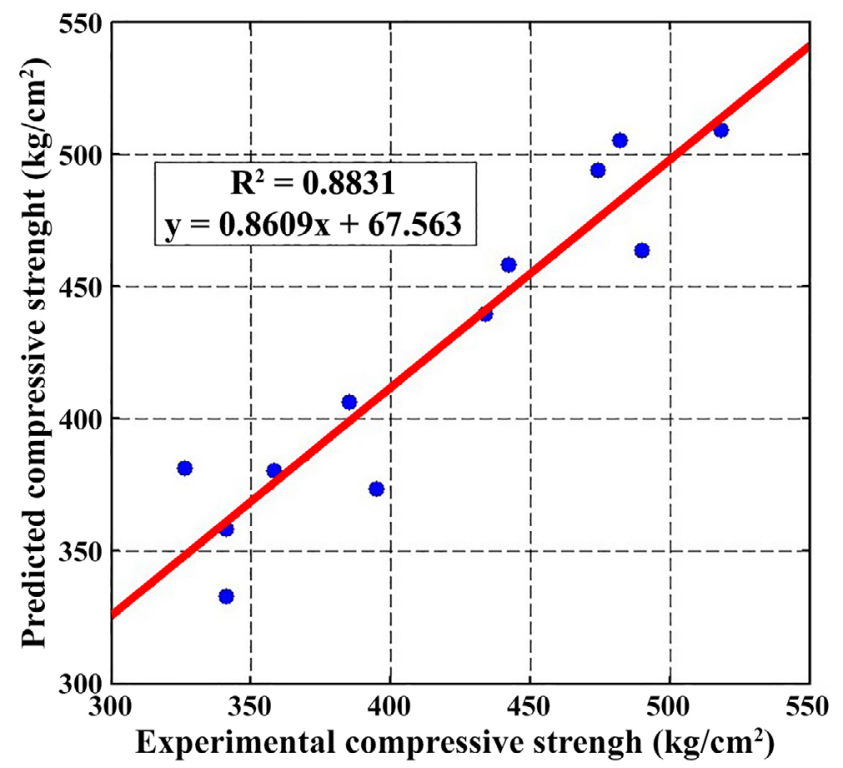

Figure 1o: Comparison of measured and predicted values by FCM-ANN model for testing data.

\subsubsection{Support vector regression}

Like the ANN model, the SVR model was developed with five input parameters (quantities of cement, water, fine aggregates, coarse aggregates, and micro silica) and one output parameter (28-day compressive strength). The LIBSVM toolbox, developed by Chang and Lin (Chang \& Lin, 2011), was used to develop the SVR model in the MATLAB environment. Given the superiority of the RBF kernel over the alternatives, the model was developed with this function. Learning parameters including the penalty factor and the deviation (width) of the RBF kernel function were determined via a grid searching method coupled with cross-validation. The model was trained with 47 data instances and evaluated using 12 data instances. In Figure 4, the outputs of this SVR model are compared with the measured compressive strength values.

\subsection{3 $\mathrm{M}_{5} \mathrm{P}$ model tree}

The M5P model tree for anticipation of the compressive strength of shotcrete was run in the machine learn-

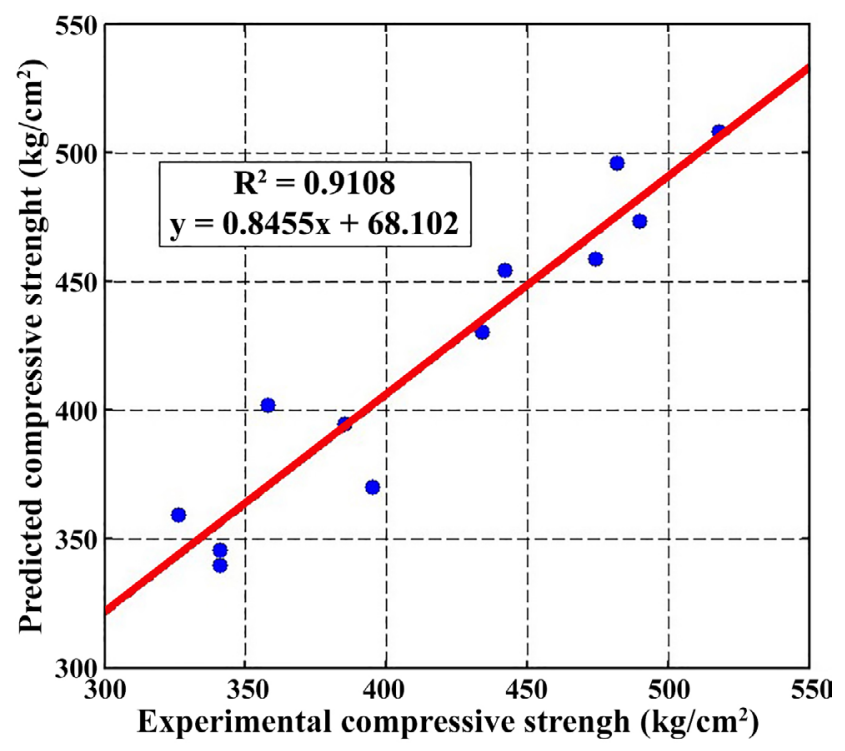

Figure 11: Comparison of measured and predicted values by FCM-SVR model for testing data.

ing utility software WEKA. The optimum value of threshold called minNumInstances, which represents the minimum number of instances allowed to be placed at each leaf and has a significant impact on the model performance, was obtained by trial and error. The M5P model tree was developed in two modes, pruned and unpruned, with minNumInstances set to 6 . Like other models, the M5P model tree was trained with the training dataset set then evaluated by the test dataset. Diagrams of the pruned and unpruned M5P model trees for prediction of the compressive strength of shotcrete are plotted in Figures 5 and 6. As can be seen, the unpruned and pruned trees consist of respectively 15 and 3 linear regression models (see Table 4). Unpruned model trees often have an excessive number of leaves which complicate the analysis and may result in overlearning and reduced generalizability. In this condition, pruning the tree by merging some of the sub-trees simplifies the model, making it more generalizable, but may slightly reduce the prediction accuracy. Scatter diagrams of the measured compressive strength values and those predicted by the pruned and unpruned model trees are plotted in Figures 7 and 8 , respectively. 


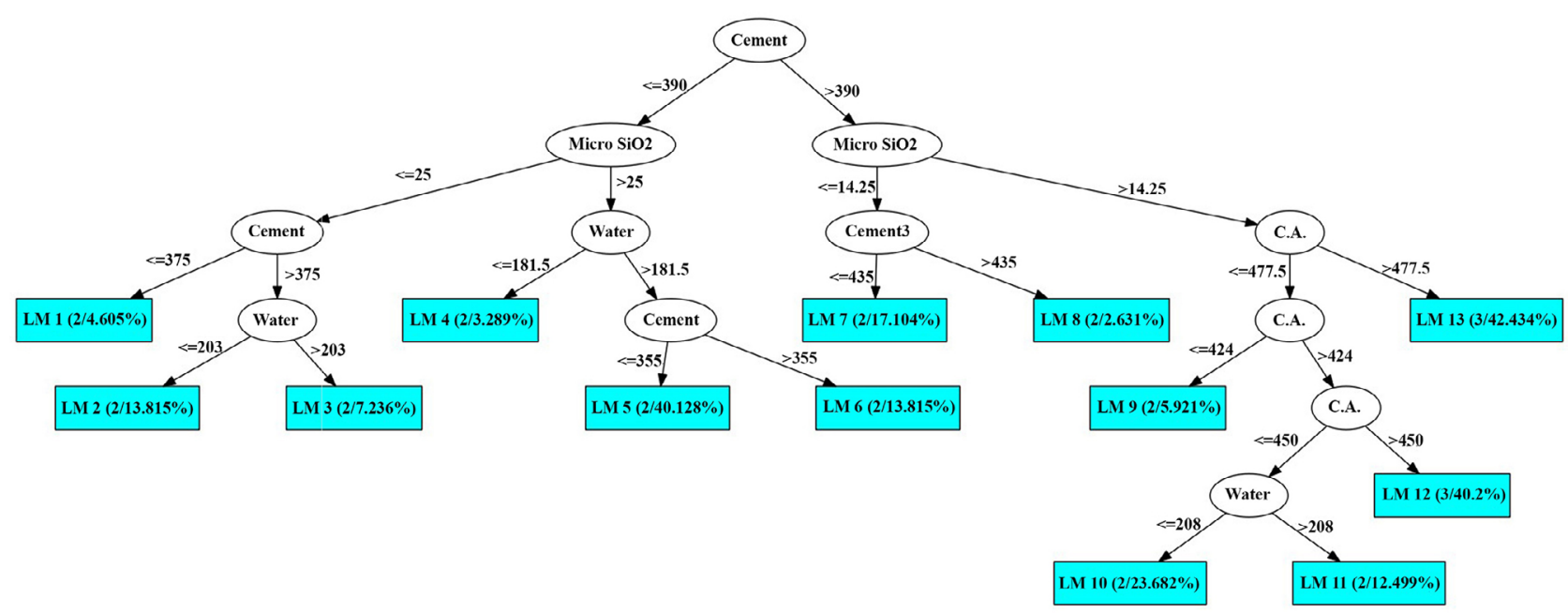

(a)



(b)

Figure 12: Structure of the unpruned $\mathrm{M}_{5} \mathrm{P}$ model tree; (a) Cluster 1, (b) Cluster 2

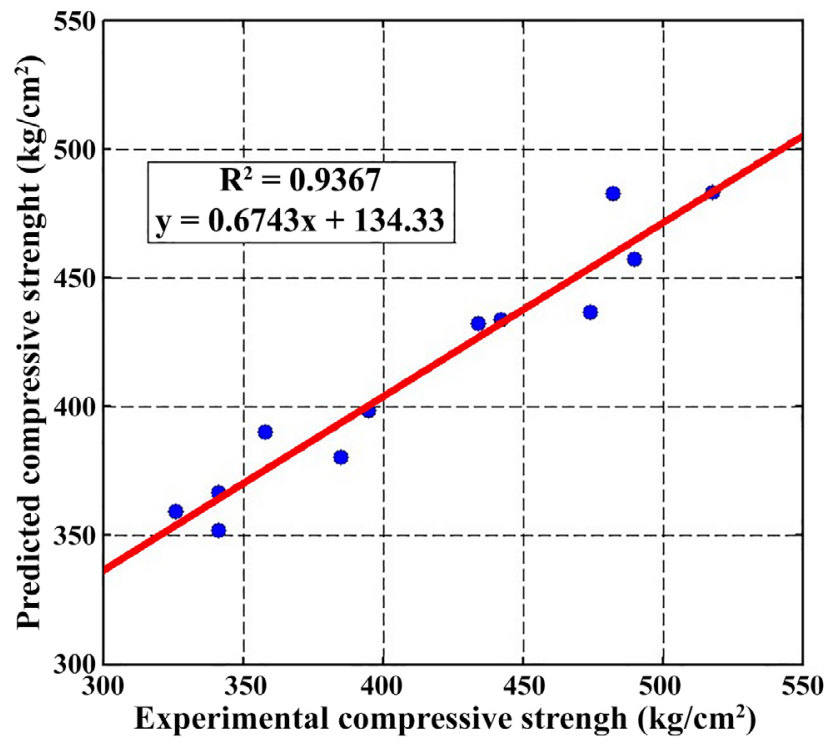

Figure 13: Comparison of measured and predicted values by unpruned $\mathrm{FCM}-\mathrm{M}_{5} \mathrm{P}$ model for testing data.

\subsection{Development of hybrid models}

Generally, most studies in the field of data mining applied individual learning techniques with minor modifications to construct single models. However, hybrid models or combinations of two or more techniques have proven superior to many individual models (J.-S. Chou et al., 2014; Frosyniotis et al., 2003). The strategy adopted in this study is to combine unsupervised FCM and supervised learning methods including ANN, SVR, and M5P Tree in a parallel setup to achieve a new group of hybrid models. The block diagram of this hybrid model is shown in Figure 9. As can be seen, first, the dataset is classified by FCM algorithm into several clusters with similar characteristics, and then ANN, SVR, and M5P Tree are applied separately to each cluster. In view of the volume of data and after evaluating the performance of learning models with a different number of clusters, this number was set to 2. Data clustering was performed using the FCM toolbox in MATLAB. The train-and-test technique, which is one of the most common approaches to establishing learning algorithms for a given database, is also used to develop the hybrid models (Ghasemi et 


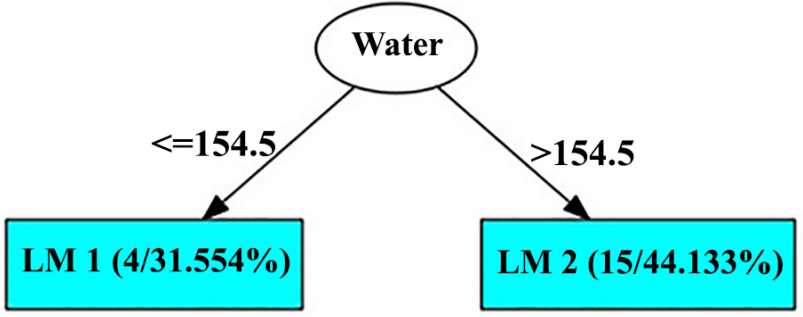

(a)

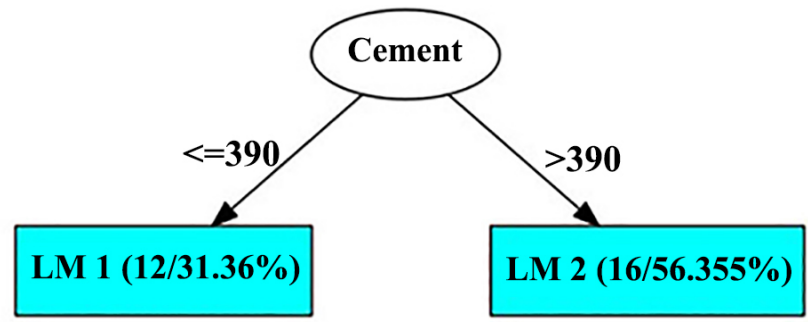

(b)

Figure 14: Structure of the unpruned $\mathrm{M}_{5} \mathrm{P}$ model tree; (a) Cluster 1, (b) Cluster 2.

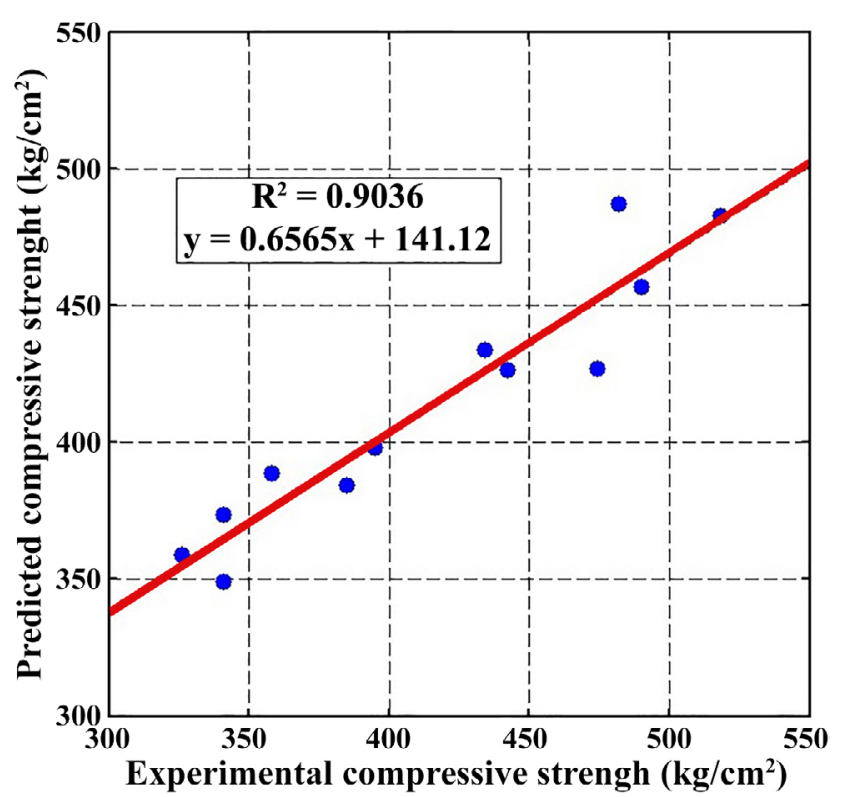

Figure 15: Comparison of measured and predicted values by pruned $\mathrm{FCM}-\mathrm{M}_{5} \mathrm{P}$ model for testing data.

al., 2017). Accordingly, the dataset was divided into two clusters, the first consisting of 35 datasets (28 datasets assigned to the training set and 7 datasets assigned to the testing set), and the second cluster consisting of 24 datasets (19 datasets assigned to the training set and 5 datasets assigned to the testing set). It should be noted that the training and testing datasets used in this phase are similar to the training and testing datasets used during the development of individual models.

\subsubsection{FCM-ANN}

Given the split of dataset into two clusters, the feedforward backpropagation ANN model was constructed for each cluster separately. The architecture of these networks is similar to that of individual ANN architecture consisting of one hidden layer composed of sigmoid neurons and a linear output layer. The number of neurons considered for the model of both clusters was 8 . The model constructed for each cluster was tested by the testing dataset of the same cluster. In Figure 10, the final results of the hybrid model are compared with the measured compressive strength values.

\subsubsection{FCM-SVR}

For each cluster, the intelligent SVR model was developed using the training dataset of that cluster. Each model was then evaluated using the testing dataset of the same cluster. The results obtained from these models are presented and compared in Figure 11.

\subsubsection{FCM-M5}

For each cluster, the FCM-M5P hybrid model was developed in two modes, pruned and unpruned. First, the unpruned M5P tree (see Figure 12) was implemented for both first and second clusters with minNumInstances set to 4 and 6 , respectively. The results of this model are presented in Figure 13. Then, the models were pruned for more simplicity. The model trees obtained in this step are shown in Figure 14. The results of evaluation of these models with the testing dataset are presented in Figure 15.

\section{Analysis of results}

Performance of the aforementioned models was evaluated based on the criteria described in section 2.6. The values of each statistical measure for the above models are presented in Table 5 .

The results show that ANN models have a weaker performance than the other two. The SVR model outperforms the ANN model, not only in accuracy, but also in execution time and memory consumption. However, the best performance among the models has been achieved

Table 5: Statistical measures of developed models.

\begin{tabular}{|l|l|l|l|l|}
\hline Models & $\mathbf{R}^{\mathbf{2}}$ & MAPE & RMSE \\
\hline ANN & 0.82 & 5.24 & 27.45 \\
\hline FCM-ANN & 0.88 & 5.23 & 23.92 \\
\hline SVR & 0.86 & 5.55 & 27.00 \\
\hline FCM-SVR & & 0.91 & 4.01 & 19.91 \\
\hline \multirow{2}{*}{ M5P } & Pruned & 0.91 & 5.22 & 26.14 \\
\cline { 3 - 5 } & Unpruned & 0.92 & 5.32 & 26.15 \\
\hline \multirow{2}{*}{ FCM-M5P } & Pruned & 0.90 & 4.98 & 25.85 \\
\cline { 3 - 5 } & Unpruned & 0.94 & 4.64 & 23.56 \\
\hline
\end{tabular}


by the M5P model trees. In these trees, pruning has slightly reduced the accuracy, but has also made a significant reduction in tree size and the operation necessary to predict the compressive strength. The most important advantage of the M5P model tree over the other two methods is the ability to create a simple tree structure with linear models in the leaves, which can explicitly describe the relationship between the input and output parameters. In other intelligent data mining techniques, completed once the model is constructed, the relative importance of its inputs need to be determined through a sensitivity analysis. However, in decision trees, the top-down structure of the tree also reveals the importance of the parameters, as the parameters placed at a higher position participate in the final prediction of a larger portion of the input instances. A comparison of hybrid models with their corresponding individual models shows the higher accuracy of hybrids. In general, it can be claimed that a phase of data clustering improves not only the prediction performance of these models, but also their generalizability, and thus their applicability to a wider range of projects.

\section{Summary and conclusion}

An accurate estimation of the compressive strength of shotcrete is important for construction and mining projects. In this study, we investigated the ability of various data mining techniques, including artificial neural network, support vector regression and M5P tree to predict the 28-day compressive strength of shotcrete, as well as the effect of using a data clustering phase prior to data mining technique on the prediction accuracy. To achieve this purpose, the mentioned techniques were used individually to develop a series of standalone prediction models. Then, these techniques were combined with FCM clustering to construct a series of hybrid models. The results of all models were compared with the outputs of the corresponding individual models. The comparisons showed that, among the tested individual models, the M5P model tree has the highest accuracy in predicting the compressive strength of shotcrete. Apart from the superior accuracy, the most important advantage of this model over the other two is its ability to derive the linear regression relations between input and output data. Analysis of the results also showed the better prediction power of the SVR model as compared to the ANN model.

This study showed that the application of a data clustering phase prior to soft computing techniques can significantly improve the performance of models in anticipating the compressive strength of shotcrete. In general, the hybrid models managed to outperform the individual models. This superiority of hybrid models was particularly significant in the case of FCM-ANN and FCMSVR in comparison with their individual counterparts. In addition to performance improvement, other benefits of data clustering phase as we described in this study include better generalizability and applicability to other projects.

\section{Data Availability Statement}

All data and models that support the findings of this study are available from the corresponding author upon reasonable request.

\section{Acknowledgements}

The authors would like to thank Professor. R. Bagherpour for providing the experimental data and helpful suggestions. In addition, the authors would like to express their thanks to the anonymous reviewer for his/her useful comments and constructive suggestions.

\section{Conflict of interest}

The authors declare that there is no conflict of interest.

\section{References}

Abrams, D. A. (1919): Design of concrete mixtures (Vol. 1): Structural Materials Research Laboratory. Lewis Institute, $75 \mathrm{p}$.

ACI 506R-05 (2005): ACI standard 506R-05 - Guide to shotcrete, ACI Committee, American Concrete Institute, www. concrete.org.

Adhikary, B. B., \& Mutsuyoshi, H. (2006): Prediction of shear strength of steel fiber RC beams using neural networks. Construction and Building Materials, 20, 9, 801-811.

Ahangar-Asr, A., Faramarzi, A., Javadi, A. A., \& Giustolisi, O. (2011): Modelling mechanical behaviour of rubber concrete using evolutionary polynomial regression. Engineering Computations, 28, 4, 492-507.

Asteris, P. G., \& Kolovos, K. G. (2017): Self-compacting concrete strength prediction using surrogate models. Neural Computing and Applications, 31, 409-424.

Ayaz, Y., Kocamaz, A. F., \& Karakoç, M. B. (2015): Modeling of compressive strength and UPV of high-volume mineraladmixtured concrete using rule-based M5 rule and tree model M5P classifiers. Construction and Building Materials, 94, 235-240.

Beale, R., \& Jackson, T. (1990): Neural Computing - An Introduction. CRC Press, New York, 256 p.

Behnood, A., Behnood, V., Modiri Gharehveran, M., \& Alyamac, K. E. (2017): Prediction of the compressive strength of normal and high-performance concretes using M5P model tree algorithm. Construction and Building Materials, 142, 199-207.

Behnood, A., Verian, K. P., \& Modiri Gharehveran, M. (2015): Evaluation of the splitting tensile strength in plain and steel fiber-reinforced concrete based on the compressive strength. Construction and Building Materials, 98, 519-529.

Bezdek, J. C. (1981): Pattern recognition with fuzzy objective function algorithms. Plenum Press, New York, 267 p. 
Bonakdar, L., \& Etemad-Shahidi, A. (2011): Predicting wave run-up on rubble-mound structures using M5 model tree. Ocean Engineering, 38, 1, 111-118.

Caudill, M. (1988): Neural networks primer, part III. AI Expert, 3, 6, 53-59.

Chang, C.-C., \& Lin, C.-J. (2011): LIBSVM: a library for support vector machines. ACM Transactions on Intelligent Systems and Technology (TIST), 2, 3, 27.

Cheng, M.-Y., Firdausi, P. M., \& Prayogo, D. (2014): Highperformance concrete compressive strength prediction using Genetic Weighted Pyramid Operation Tree (GWPOT). Engineering Applications of Artificial Intelligence, 29, 0, 104-113.

Chithra, S., Kumar, S. R. R. S., Chinnaraju, K., \& Alfin Ashmita, F. (2016): A comparative study on the compressive strength prediction models for High Performance Concrete containing nano silica and copper slag using regression analysis and Artificial Neural Networks. Construction and Building Materials, 114, 528-535.

Chou, J.-S., \& Pham, A.-D. (2013): Enhanced artificial intelligence for ensemble approach to predicting high performance concrete compressive strength. Construction and Building Materials, 49, 554-563.

Chou, J.-S., Tsai, C.-F., Pham, A.-D., \& Lu, Y.-H. (2014): Machine learning in concrete strength simulations: Multi-nation data analytics. Construction and Building Materials, 73, 771-780.

Chou, J., Chiu, C., Farfoura, M., \& Al-Taharwa, I. (2010): Optimizing the Prediction Accuracy of Concrete Compressive Strength Based on a Comparison of Data-Mining Techniques. Journal of Computing in Civil Engineering, 25, 3, 242-253.

Cortes, C., \& Vapnik, V. (1995): Support-vector networks. Machine Learning, 20, 3, 273-297.

Dunn, J. C. (1973): A Fuzzy Relative of the ISODATA Process and Its Use in Detecting Compact Well-Separated Clusters. Journal of Cybernetics, 3, 3, 32-57.

Esme, E., \& Karlik, B. (2016): Fuzzy c-means based support vector machines classifier for perfume recognition. Applied Soft Computing, 46, 452-458.

Etemad-Shahidi, A., \& Ghaemi, N. (2011): Model tree approach for prediction of pile groups scour due to waves. Ocean Engineering, 38, 13, 1522-1527.

Etemad-Shahidi, A., \& Mahjoobi, J. (2009): Comparison between M5' model tree and neural networks for prediction of significant wave height in Lake Superior. Ocean Engineering, 36, 15, 1175-1181.

Fausett, L. V. (1994): Fundamentals of Neural Networks: Architectures, Algorithms, and Applications. Prentice-Hall, $461 \mathrm{p}$.

Friedman, M., \& Kandel, A. (1999): Introduction to pattern recognition: statistical, structural, neural and fuzzy logic approaches, 32, 168-181.

Feng, D.-C., Liu, Z.-T., Wang, X.-D., Chen, Y., Chang, J.-Q., Wei, D.-F., \& Jiang, Z.-M. (2020): Machine learningbased compressive strength prediction for concrete: An adaptive boosting approach. Construction and Building Materials, 230, 117000.
Franzen, T., Garshol, K. F., \& Tomisawa, N. (2001): Sprayed concrete for final linings: ITA working group report. Tunnelling and Underground Space Technology, 16, 4, 295-309.

Frosyniotis, D., Stafylopatis, A., \& Likas, A. (2003): A divideand-conquer method for multi-net classifiers. Pattern Analysis \& Applications, 6, 1, 32-40.

Ganesh, A. C., \& Muthukannan, M. (2021): Development of high performance sustainable optimized fiber reinforced geopolymer concrete and prediction of compressive strength. Journal of Cleaner Production, 282, 124543.

Ghasemi, E., Kalhori, H., \& Bagherpour, R. (2016): A new hybrid ANFIS-PSO model for prediction of peak particle velocity due to bench blasting. Engineering with Computers, 32, 4, 607-614.

Ghasemi, E., Kalhori, H., \& Bagherpour, R. (2017): Stability assessment of hard rock pillars using two intelligent classification techniques: A comparative study. Tunnelling and Underground Space Technology, 68, 32-37.

Ghasemi, E., Kalhori, H., Bagherpour, R., \& Yagiz, S. (2018): Model tree approach for predicting uniaxial compressive strength and Young's modulus of carbonate rocks. Bulletin of Engineering Geology and the Environment, 77, 1, 331-343.

Golafshani, E. M., \& Ashour, A. (2016): Prediction of selfcompacting concrete elastic modulus using two symbolic regression techniques. Automation in Construction, 64, 7-19.

Golafshani, E. M., \& Behnood, A. (2018): Application of soft computing methods for predicting the elastic modulus of recycled aggregate concrete. Journal of Cleaner Production, 176, 1163-1176.

Gunn, S. R. (1998): Support vector machines for classification and regression. ISIS technical report, 14, 1, 5-16.

Hammoudi, A., Moussaceb, K., Belebchouche, C., \& Dahmoune, F. (2019): Comparison of artificial neural network (ANN) and response surface methodology (RSM) prediction in compressive strength of recycled concrete aggregates. Construction and Building Materials, 209, 425-436.

Hecht-Nielsen, R. (1989). Kolmogorov's mapping neural network existence theorem. Paper presented at the Proceedings of the International Joint Conference in Neural Networks, 3, 11-14.

Hoang, N.-D., Pham, A.-D., Nguyen, Q.-L., \& Pham, Q.-N. (2016): Estimating Compressive Strength of High Performance Concrete with Gaussian Process Regression Model. Advances in Civil Engineering, 2016, 2861380.

Janković, K., Nikolić, D., Bojović, D., Lončar, L., \& Romakov, Z. (2011): The estimation of compressive strength of normal and recycled aggregate concrete. Facta universitatis-series: Architecture and Civil Engineering, 9, 3, 419-431.

Kaastra, I., \& Boyd, M. (1996): Designing a neural network for forecasting financial and economic time series. Neurocomputing, 10, 3, 215-236.

Kalhori, H., \& Bagherpour, R. (2017): Application of carbonate precipitating bacteria for improving properties and repairing cracks of shotcrete. Construction and Building Materials, 148, 249-260. 
Kalhori, H., \& Bagherpour, R. (2019): Prediction of shotcrete compressive strength using Intelligent Methods; Neural Network and Support Vector Regression. CEMENT WAPNO BETON, 24, 2, 126.

Kaloop, M. R., Kumar, D., Samui, P., Hu, J. W., \& Kim, D. (2020): Compressive strength prediction of high-performance concrete using gradient tree boosting machine. Construction and Building Materials, 264, 120198.

Kanellopoulos, I., \& Wilkinson, G. (1997): Strategies and best practice for neural network image classification. International Journal of Remote Sensing, 18, 4, 711-725.

Khoshnoudian, F., Ahmadi, E., \& Nik, F. A. (2013): Inelastic displacement ratios for soil-structure systems. Engineering Structures, 57, 453-464.

Khademi, F., Akbari, M., Jamal, S. M., \& Nikoo, M. (2017): Multiple linear regression, artificial neural network, and fuzzy logic prediction of 28 days compressive strength of concrete. Frontiers of Structural and Civil Engineering, 11, 1, 90-99.

Madandoust, R., Bungey, J. H., \& Ghavidel, R. (2012): Prediction of the concrete compressive strength by means of core testing using GMDH-type neural network and ANFIS models. Computational Materials Science, 51, 1, 261-272.

Martins, F. F., \& Camões, A. (2013): Prediction of compressive strength of concrete containing fly ash using data mining techniques.

Moffat, R., Jadue, C., Beltran, J. F., \& Herrera, R. (2017): Experimental evaluation of geosynthetics as reinforcement for shotcrete. Geotextiles and Geomembranes, 45, 3, 161-168.

Naderpour, H., Rafiean, A. H., \& Fakharian, P. (2018): Compressive strength prediction of environmentally friendly concrete using artificial neural networks. Journal of Building Engineering, 16, 213-219.

Nikoo, M., Torabian Moghadam, F., \& Sadowski, Ł. (2015): Prediction of Concrete Compressive Strength by Evolutionary Artificial Neural Networks. Advances in Materials Science and Engineering, 2015, 849126.

Nikoo, M., Zarfam, P., \& Sayahpour, H. (2015): Determination of compressive strength of concrete using Self Organization Feature Map (SOFM). Engineering with Computers, 31, 1, 113-121.

Quinlan, J. R. (1992). Learning with continuous classes. Paper presented at the 5th Australian joint conference on artificial intelligence, 92, 343-348.

Ripley, B. D. (1993): Statistical aspects of neural networks. Networks and chaos - statistical and probabilistic aspects, 50, 40-123.

Ren, Y., Guan, W., Liu, W., Xi, J., \& Zhu, L. (2019): Facial semantic descriptors based on information granules. Information Sciences, 479, 335-354.

Safarzadegan Gilan, S., Bahrami Jovein, H., \& Ramezanianpour, A. A. (2012): Hybrid support vector regression - Par- ticle swarm optimization for prediction of compressive strength and RCPT of concretes containing metakaolin. Construction and Building Materials, 34, 321-329.

Sarıdemir, M. (2009): Predicting the compressive strength of mortars containing metakaolin by artificial neural networks and fuzzy logic. Advances in Engineering Software, 40, 9, 920-927.

Sarıdemir, M. (2010): Genetic programming approach for prediction of compressive strength of concretes containing rice husk ash. Construction and Building Materials, 24, 10, 1911-1919.

Sobhani, J., Khanzadi, M., \& Movahedian, A. (2013): Support vector machine for prediction of the compressive strength of no-slump concrete. Computers and Concrete, 11, 4, 337-350.

Sobhani, J., Najimi, M., Pourkhorshidi, A. R., \& Parhizkar, T. (2010): Prediction of the compressive strength of noslump concrete: A comparative study of regression, neural network and ANFIS models. Construction and Building Materials, 24, 5, 709-718.

Silva Filho, T. M., Pimentel, B. A., Souza, R. M., \& Oliveira, A. L. (2015): Hybrid methods for fuzzy clustering based on fuzzy c- means and improved particle swarm optimization. Expert Systems with Applications, 42, 17-18, 6315-6328.

Taffese, W. Z., \& Sistonen, E. (2017): Significance of chloride penetration controlling parameters in concrete: Ensemble methods. Construction and Building Materials, 139, 9-23.

Tenza-Abril, A. J., Villacampa, Y., Solak, A. M., \& Baeza-Brotons, F. (2018): Prediction and sensitivity analysis of compressive strength in segregated lightweight concrete based on artificial neural network using ultrasonic pulse velocity. Construction and Building Materials, 189, 1173-1183.

Thomas, A. (2008): Sprayed concrete lined tunnels. Taylor \& Francis, New York, 308 p.

Wang, Y., \& Witten, I. H. (1997). Induction of model trees for predicting continuous classes. Paper presented at the In: Proc. of the 9th European Conf. on Machine Learning Poster Papers, University of Economics, Faculty of Informatics and Statistics, Prague, 96, 128-137.

Watanabe, T., Hosomi, M., Yuno, K., \& Hashimoto, C. (2010): Quality evaluation of shotcrete by acoustic emission. Construction and Building Materials, 24, 12, 2358-2362.

Yuan, Z., Wang, L.-N., \& Ji, X. (2014): Prediction of concrete compressive strength: Research on hybrid models genetic based algorithms and ANFIS. Advances in Engineering Software, 67, 156-163.

Yücel, K. T., \& Özel, C. (2012): Modeling of mechanical properties and bond relationship using data mining process. Advances in Engineering Software, 45, 1, 54-60.

Zhu, L., Zhao, C., \& Dai, J. (2021): Prediction of compressive strength of recycled aggregate concrete based on gray correlation analysis. Construction and Building Materials, $273,121750$. 


\section{SAŽETAK}

\section{Primjena metodologija mekoga računarstva u predviđanju 28-dnevne tlačne čvrstoće mlaznoga betona: komparativna usporedba individualnoga i hibridnoga modela}

Mlazni beton popularna je konstrukcijska tehnika široke uporabe u rudarstvu i građevinarstvu. Tlačna čvrstoća primarno je mehaničko svojstvo mlaznoga betona s posebnom važnošću za sigurnost projekta, ovisno o sastavu betona. U praksi ne postoji pouzdana i točna metoda za predviđanje toga svojstva. Ovdje su prikazani eksperimentalni podatci za 59 različitih sastava mlaznoga betona, na kojima je razvijen niz metodologija temeljem mekoga računarstva, uključujući pojedinačnu umjetnu neuronsku mrežu, podržanu vektorskom regresijom, stablastim dijagramima, njihovim hibridima na temelju klastera vrijednosti c-sredina, a s ciljem predviđanja promjene tlačne čvrstoće mlaznoga betona tijekom 28 dana. Općenito su klasteri podataka već prije uporabe strojnoga učenja znatno pomogli u kvaliteti, pouzdanosti i općenitosti rezultata. Posebno je istaknut stablasti model $\mathrm{M}_{5} \mathrm{P}$ kao onaj koji izvrsno predviđa tlačnu čvrstoću mlaznoga betona.

\section{Ključne riječi:}

mlazni beton, tlačna čvrstoća, tehnike strojnoga učenja, hibridni model

\section{Authors contribution}

Mahtab Torkan, M.Sc, performed the design and implementation of the research. Hamid Kalhori, the Ph.D. student, wrote the manuscript and collected the data. Mohammad Hosein Jalalian, M.Sc, contributed to the analysis of the results and edited the manuscript. 